JSACE $1 / 28$

Effects of Design Quality on Delay in Residential Construction Projects

Received 2020/11/05

Accepted after revision $2021 / 05 / 22$

\section{Effects of Design Quality on Delay in Residential Construction Projects}

\section{Ibrahim Mahamid*}

Civil Engineering Department, Faculty of Engineering, University of Prince Mugrin, Madinah, KSA and Arab American University Palestine

*Corresponding author: imahamid@ymail.com

$\Gamma$ Crossef http://dx.doi.org/10.5755/j01.sace.28.1.20531

This study is conducted to establish the effect of design quality on project delay in building projects. It aims at: 1) investigating the major factors of design quality, 2) identifying the main delay factors in building projects, 2) establishing the relationship between design quality and delay in building projects. To achieve these objectives, a questionnaire survey is performed. Seventeen (17) factors that might affect design quality, and 15 delay factors are listed in a questionnaire form. Sixty (60) contractors and 40 consultants are asked to identify the severity of the identified factors. Results indicate that the top factors affecting design quality are: delay in payments by client for design services, staff allocation for many projects at the same time, copying and modifying from previous work to minimize time and cost, tight design schedule, lack of designer knowledge with techniques and materials available in the market. The study also concludes that the top five delay factors include: payments delay, poor labor productivity, lack of skilled manpower, frequent change orders and rework. Regression analysis for data collected from 36 building projects shows a good correlation between design quality and delay in projects. This study is the first one that addresses the problem of design quality in the West Bank in Palestine. Furthermore, it is the first study that addresses the effect of design quality on project delay in Palestine and the neighboring countries. It is hoped to be helpful for researchers and professionals to understand the impact of design quality on schedule delay.

Keywords: buildings, delay, design, quality, time overrun.

Construction industry has a major impact on the economic improvement for any country. It involves many resources, namely: finance, machinery, raw materials, technology and human resource. It also involves many parties such as: clients, consultants, designers, contractors, subcontractors, and suppliers. However, the management process of construction projects is complicated due to many resources and parties involved in it. Enshassi et al. (2003) stated that "the increasing complexity of infrastructure projects and the environment within which they are constructed place greater demand on construction managers to deliver projects on time, within the planned budget and with high quality". Previous studies revealed that most of construction projects completed with schedule delay. For instance, Omoregie and Radford (2006) concluded that the average time deviation in construction projects in Nigeria is 188\%. Faridi and El-Sayegh (2006) found that $50 \%$ of construction projects in UAE completed with time overrun. Assaf and AlHejji (2006) indicated that 70\% of construction projects implemented in Saudi Arabia completed with schedule delay. Mahamid et al. (2012) revealed that $95 \%$ of highway construction projects in Palestine completed with delay with average value of $37 \%$. Schedule delay has severe impact on project success. It is one of the main factors result in project failure in construction projects. It 
causes cost overrun, disputes, conflicts and quality deficiencies on site which negatively affect the relation between construction parties, equally the project performance.

Design plays a major role in construction projects. design quality influences the overall project performance. It also has main effect on project performance (Couto, 2012). improper planning and design management during design phase leads to project failure (Williams and Johnson, 2014). Pandit (2015) stated that "problems during design development contribute significantly to delays". Mahamid and Bruland (2011) linked cost overrun of highway projects to lack of time for estimates, mistakes in drawings, changes in design, and unclear specifications. In their study, they concluded that out of 51 identified factors, the top five factors affecting cost overrun include two factors that are related to design, namely: incomplete drawing and lack of designers' experience. Durdyev et al. (2010) found that frequent design changes contribute to cost overrun and project delay in building projects. Kpamma and Adjei-Kumi (2011) concluded that the waste is generated during design phase and consultants are unable to manage it. It has high impact on project delay and cost overrun. Gobang et al. (2020) attributes time overrun of highway projects to delay in decision making by the client, design mistakes and errors, frequent design changes by client and consultant, and approvals from stakeholders. Out of total 36 factors identified in Gobang's et al. (2020) study, the top four factors influencing time overrun include two factors that are related to design, namely: design errors and design changes.

Literature review show that very little or no studies have investigated the relationship between design quality and schedule delay in building projects. This study is the first one that addresses the problem of design quality in the West Bank in Palestine. Furthermore, it is the first study that addresses the effect of design quality on project delay in Palestine and the neighboring countries. This paper aims at: (1) identifying factors of design quality that may have significant impact on project results, (2) identifying factors affecting schedule delay, (3) establishing the relationship between design quality and schedule delay. Construction parties need to have a full list of factors that might affect project results and to understand the relation between these factors, and therefore prioritize their efforts to eliminate them and to improve performance in construction projects.

\section{Factors affecting design quality in building projects}

The design quality has a main impact on project performance and efficiency in construction projects. Poor standards of design quality contribute to poor performance in construction projects (Abdelaziz, 2009). A study conducted in Gaza found that the most significant factors affecting design quality in construction projects are: poor skills of consultant's staff, lack of time allowed for checking of design documents, lack of experience, unfamiliarity of designers with construction techniques used in the project and absence of good design manager. On the other hand, the study concluded that the most occurred factors are: low design fees, selection of designers with lowest price, allocation of staff to many projects, frequent changes by client and unwillingness of clients to pay fees for design of high-quality (Abdelaziz, 2009). Love et al. (2006) revealed that "mistakes in design" is a major factor that affects rework cost in construction projects. Pandit (2015) addressed the main factors influencing design quality in construction projects. He concluded that the top factors include: parameters of structural design, soil tests, control of quality, survey works, and parameter of architectural design.

Design mistakes lead to rework which influences the overall performance in building projects ( $\mathrm{Li}$ and Taylor, 2014). To reduce the effect of design rework in construction projects, Li and Taylor (2014) recommended strategies to enhance design quality. Lopez and Love (2012) investigated 139 construction projects. They concluded that the cost of design mistakes is $6.85 \%$ of the total project cost. Couto (2012) concluded that omissions and errors in designs result in claims and disputes in projects. Durdyev et al. (2010) indicated that the main factors affecting design management are: lack of site investigation and frequent changes in design. Ali et al. (2012) stated 
that design deficiencies is one of the significant factors result in cost overrun, schedule delay and quality deviations in construction projects. In a study conducted in Jordan, it is found that poor design brief and errors in parameters of design are main factors affecting time overrun in public construction projects (Sweis's, 2013).

\section{Factors affecting schedule delay in building projects}

Schedule delay is defined as "the time difference between the actual completion time and the estimated completion time, agreed by and between the client and the contractor during signing of the contract" Mahamid et al. (2012). The problem of schedule delay in one of the main problems in construction industry (Kaliba et al., 2009; Mahamid, 2017b; Santoso and Soeng, 2016). Mahamid (2017a) found that the average of delay in highway construction projects in Saudi Arabia is $58.24 \%$, ranging from $2 \%$ to $172 \%$. Al-Najjar (2008) addressed the main delay factors in building projects in Gaza Strip, they are: strikes, political problems, shortage of construction materials, cash problems, improper site management, economic problems, unavailable equipment, tool shortage and payments delay by the owner.

Kaliba et al. (2009) identified the main causes of time overrun in construction projects, namely: payments delay, financial problems, frequent changes, lack in equipment, design mistakes, conflicts and disputes, and strikes. In Malaysia, Memon et al. (2012) indicated that the significant delay factors include: design deficiencies, financial difficulties, poor management, improper site management and communication technology. Mahamid et al. (2012) addressed delay factors in highway projects in Palestine. Contractors concluded that the top five factors are: segmentation, political situation, payment delay, delay in decision making and poor productivity. In the same study, the consultants found that the main factors are: political conditions, limitation on movement, lowest bid price strategy, lack in equipment and unreasonable schedule. Among various factors that causes schedule delay in construction projects, financial difficulties, improper planning and management, inadequate experience, and unavailability of labors top the list (Memon et al., 2014). Mahamid et al. (2015) conducted a study in Saudi Arabia to identify the main factors contributing to project delay in highway construction projects. They concluded that the top factors are: bid awarding policy, variations in specifications, contract management, tight time for bidding, changes in materials price, design variations, improper planning, lack of skilled labors, poor productivity and rework. Msafiri (2015) addressed delay causes in building projects in Kenya. The top factors are: delay in payments by client, lack of planning, late decision and weather effects. Al-Hazim and Abusalem (2015) concluded that terrain and weather are the significant factors affecting schedule delay in construction projects. Santoso and Soeng (2016) found that the significant contributor to project delay are: bidding policy, inefficient equipment, site management, terrain, payments delay and poor labor productivity. Mahamid (2017b) linked schedule delay in highway projects with the physical characteristics of the project. Good correlation between delay and ground conditions is addressed. Furthermore, Mahamid (2017a) study revealed the top delay factors, they are: poor planning, lack of productivity, rework, poor experience and additional works. The study indicated that project delay contributes to severe problem on site such as: cost deviations, conflicts, disputes, arbitration, litigation, and quality deviations. Gobang et al. (2020) revealed that the main factors affecting construction delay in Saudi Arabia are: delay in decision making by the client, design mistakes and errors, frequent design changes by client and consultant, and approvals from stakeholders.

In summary, literature review shows that little studies were conducted to address the problem of deign quality in construction projects. Therefore, more studies should be conducted to address this important area in construction industry. While many studies were investigated the main factors of schedule delay in construction projects. However, this is the first study that addresses 
the effects of design quality on project delay. Therefore, it is important and could be helpful for researchers and professionals as well. The study pays the attention of construction parties to the effects of design quality on project delay, so they can improve performance of construction projects. It is very clear that better design quality could positively affect project outcomes.

When the study objectives set, the following steps are followed to achieve them:

1. Literature review is done to find out the factors affecting design quality and schedule delay are identified. Seventeen (17) influencing design quality and 15 factors affecting schedule delay are identified.

2. A questionnaire is designed. It includes 3 parts: part 1 asks about respondent and company, part 2 includes the list of factors affecting design quality, and part 3 included the list of factors affecting schedule delay. Participants are asked to rank the listed factors using a 5-point Linkert scale from 1 (very low severity) to 5 (very high severity).

3. Pilot study is conducted distribution the questionnaire. The pilot study aims to check the validity of the questions from the viewpoint of 3 local experts in construction projects. The experts show that the questions are suitable to achieve the study objectives and slight modifications made by them.

4. Distribution and collection: in this step, the questionnaire is distributed for the target population in this study. The target population are consultants and contractors that are specialized in residential building construction. Questionnaire are distributed and collected using the following methods: hand distribution and collection, fax and email.

5. Data analysis: Statistical Package for the Social Science (SPSS) is used to analyze the data. Average score for each factor is used to rank the identified factors. To check the correlation between the respondents, Spearman rank correlation is used.

6. After ranking the identified factors, factor analysis is used to find out the significant factors affecting design quality. Only factors with Eigen value $\geq 1.0$ (significant factors) are retained. After identifying the significant factors affecting design quality, a questionnaire is sent to the participants to identify the effect of these factors on schedule delay. The participants show the effect of these factors using a scale from 0 (no effect) to 4 (extreme effect).

7. Case study: to develop a mathematical model that shows the relation between design quality and schedule delay, a case study is conducted using data from 36 building projects (details are in section 4.5).

\section{Study population}

The target population are: 1) Consultants who have valid membership in Palestinian Engineers Association, and have experience in building construction projects, 2) Contractors who have membership in the Palestinian Contractors Union (PCU. Total of 185 registered contractors of grade 1, grade 2 and grade 3 , and 90 consultants with valid membership are targeted. To calculate the representative sample size, equation 1 is used (Emory, 1980):

$$
\mathrm{n}=(\mathrm{ts} / \mathrm{d})^{2} /\left[1+(\mathrm{ts} / \mathrm{d})^{2} / \mathrm{N}\right]
$$

where: $\mathrm{n}$ - size of sample; $\mathrm{N}$ - population sample; $\mathrm{t}$ - abscissa of the normal curve that cuts of an area of $\alpha-0.01$ at the tails $(t=2) ; d$ - expected error in the estimate $(d=0.01) ; s$ - max. standard deviation in proportion of estimation $-\mathrm{P} \times \mathrm{q}($ at $\mathrm{P}=0.5$ and $\mathrm{q}=1-\mathrm{P}=0.5)$

Table 1 shows the calculation of a representative sample. The calculation is continued until the difference between $n$ and $n-1$ is small 


\begin{tabular}{cc|c|c}
\hline $\begin{array}{c}\text { Table 1 } \\
\text { Calculation of a } \\
\text { representative sample }\end{array}$ & $\begin{array}{c}\text { Population \# } \\
\text { (contractors) }\end{array}$ & $\begin{array}{c}\text { Population \# 2 } \\
\text { (consultants) }\end{array}$ \\
\cline { 2 - 4 } & 185 & 90 \\
\hline$n_{0}$ & 84 & 57 \\
\hline$n_{2}$ & 55 & 42 \\
\hline$n_{3}$ & 41 & 33 \\
\hline$n_{4}$ & 33 & 27 \\
\hline$n_{5}$ & 27 & 23 \\
\hline$n_{6}$ & 23 & 20 \\
\hline$n_{7}$ & 20 & 18 \\
\hline
\end{tabular}

Fig. 1

Positions of the respondents

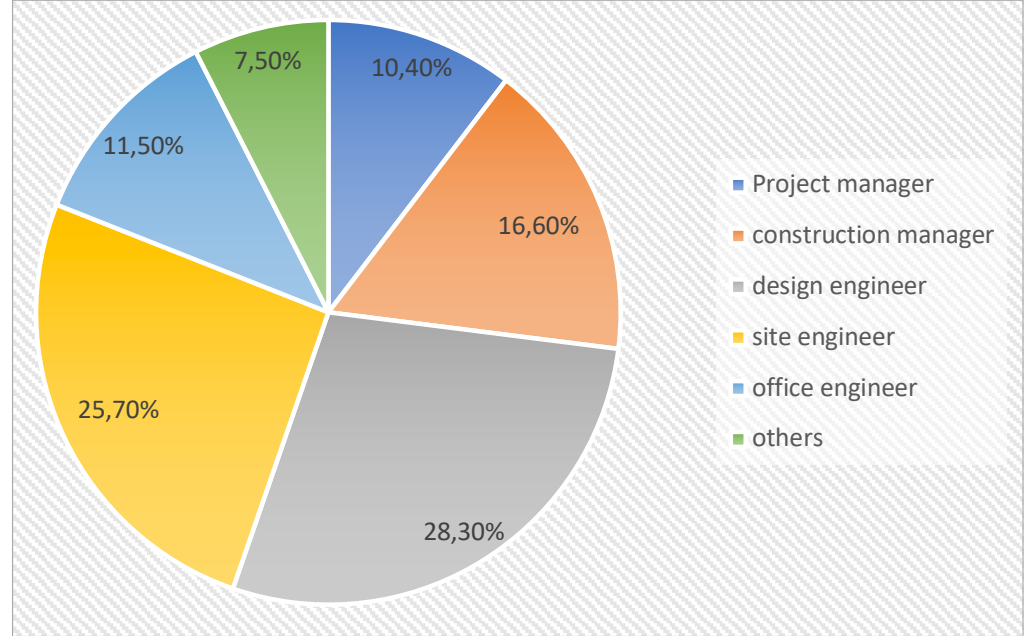

Eighty-eight (88) questionnaires are received (88 \%) as follows: $52(86.67 \%)$ from contractors, and 36 (90\%) from consultants. The participants have average experience of more than 10 years in residential projects.

Regarding the positions of the respondents, Fig. 1 shows that the respondents

experienced office engineers are (10.4\%), site engineers (25.7\%), designers (28.3\%), construction manager (16.6\%), project managers (10.4\%) and others (7.5\%).

\section{Spearman rank correlation}

Spearman rank correlation test measures the correlation between contractors and consultants on the severity of design quality factors and schedule delay factors. The value of spearman correlation $\left(r_{s}\right)$ is ranging from $(-1)$ to $(+1)$, a value of $(+1)$ shows a full positive correlation and a value of $(-1)$ indicates a full negative correlation. Values in between shows a correlation less than perfect. Equation 2 used to calculate the value of $r_{s}$ (Harnett and Murphy, 1975):

$$
r_{s}=1-\left[6 * \sum d^{2} /\left(n^{3}-n\right)\right]
$$

where: $r_{s}$ - coefficient of Spearman rank correlation; $d$ - difference between ranks on one variable and ranks on the other variable; $n$ - number of factors

\section{Results and Discussion}

\section{Ranking of factors of schedule delay in building construction projects}

Fifteen (15) factors that might affect project delay are identified through previous studies and feedback from experts in building projects. Contractors and consultants used a 5-point Likert scale to recognize the rank of the identified factors. Table 2 shows that the overall ranking identifies 
"payments delay", "poor labor productivity", “lack of skilled manpower", "frequent change orders" and "rework" are the top factors affecting schedule delay. These factors are identified by both contractors and consultants as major factors but in different ranks.

\begin{tabular}{l|c|c|c|c|c|c}
\hline \multicolumn{1}{|c|}{ Factor } & \multicolumn{2}{c}{ Consultants } & \multicolumn{2}{c}{ Contractors } & \multicolumn{2}{c}{ Overall } \\
\cline { 2 - 6 } & S.I & Rank & S.I & Rank & S.I & Rank \\
\hline payments delay & 4.16 & 1 & 4.25 & 1 & 4.21 & 1 \\
\hline poor labor productivity & 4.07 & 2 & 4.12 & 3 & 4.10 & 2 \\
\hline lack of skilled manpower & 3.95 & 3 & 4.17 & 2 & 4.08 & 3 \\
\hline frequent changes orders & 3.92 & 4 & 3.99 & 5 & 3.96 & 4 \\
\hline rework & 3.83 & 5 & 4.03 & 4 & 3.94 & 5 \\
\hline lack of coordination between construction parties & 3.69 & 6 & 3.90 & 6 & 3.82 & 6 \\
\hline poor relationship between managers and labors & 3.45 & 8 & 3.78 & 7 & 3.64 & 7 \\
\hline contractor poor financial conditions & 3.59 & 7 & 3.65 & 8 & 3.62 & 8 \\
\hline mistakes in design & 3.25 & 10 & 3.64 & 9 & 3.48 & 9 \\
\hline lack of contractor experience & 3.30 & 9 & 3.58 & 11 & 3.47 & 10 \\
\hline number of projects going at the same time & 3.06 & 11 & 3.62 & 10 & 3.39 & 11 \\
\hline disputes on site & 2.96 & 12 & 3.38 & 13 & 3.21 & 12 \\
\hline poor site management & 2.68 & 15 & 3.55 & 12 & 3.19 & 13 \\
\hline additional work & 2.73 & 14 & 3.29 & 14 & 3.06 & 14 \\
\hline effects of weather & 2.82 & 13 & 3.16 & 15 & 3.02 & 15 \\
\hline
\end{tabular}

"payments delay" leads to many problems on site that negatively affect the smooth progress of the projects. These problems include poor productivity, poor motivation, bad relation between construction parties, conflicts and disputes. This result is in line with Al-Najjar (2008), Kaliba et al. (2009) and Mahamid et al. (2012). "Poor labor productivity" indicates that the activity takes more time than planned. Many factors may lead to poor productivity on site such as payment delay, low wages, poor skills, project complexity ...etc. It should be noted that construction labor cost percentage is between 20 and $40 \%$ of total cost which means that labors have important role in building projects and the success of project is directly affected by their productivity. Therefore, labors should be motivated to improve their productivity. This conclusion agrees with Mahamid (2017a), Santoso and Soeng (2016) and Mahamid et al. (2012). "Lack of skilled manpower" is a main problem in Palestinian construction market. This is due to low wages that the labors get in comparison with what they obtained in Israeli construction market. Therefore, the high skilled labors prefer to work in Israel to obtain better wages. Poor skills lead to many problems in building projects such as poor productivity, bad quality, rework, conflicts and disputes. This result agrees with Memon et al. (2014) and Mahamid et al. (2015). "frequent change orders" and "rework" indicate that more time and efforts are required to complete the same activity. These results are in line with Kaliba et al. (2009), Mahamid et al. (2015) and Mahamid (2017a).

\section{Ranking of factor affecting design quality}

Seventeen (17) factors affecting design quality in building projects are identified through literatures and opinions of local construction experts. Respondents use 5-point Likert scale rank the identified factors. Consultants indicate that the main 5 factors affecting design quality are: delay in payments
Table 2

Ranking of factors affecting delay in residential building projects 
by client for design services, staff allocation for many projects at the same time, tight design schedule, copying and modifying from previous work to minimize time and cost and selection of designers based on lowest price. Contractors input shows that the major factors affecting design quality in building projects are: delay in payments by client for design services, copying and modifying from previous work to minimize time and cost, staff allocation for many projects at the same time, tight design schedule and lack of designer knowledge with techniques and materials available in the market. Overall ranking finds that the top five factors are: delay in payments by client for design services, staff allocation for many projects at the same time, copying and modifying from previous work to minimize time and cost, tight design schedule, lack of designer knowledge with techniques and materials available in the market. Only two factors out of the top five factors revealed by previous studies as significant factors affecting design quality, namely: "staff allocation for many projects at the same time" and "lack of designer knowledge with techniques and materials available in the market". These factors are concluded in a study conducted by Abdelaziz (2009).

Factor analysis is used to conclude the top significant factors affecting design quality in building projects. All factors that have Eigen value $\geq 1.0$ (significant factors) are retained. Only 4 factors with

\begin{tabular}{|c|c|c|c|c|c|c|c|}
\hline \multirow{3}{*}{$\begin{array}{r}\text { Table } 3 \\
\text { Ranking of design } \\
\text { quality factors in } \\
\text { building construction } \\
\text { projects }\end{array}$} & \multirow{2}{*}{ Factor } & \multicolumn{2}{|c|}{ Consultants } & \multicolumn{2}{|c|}{ Contractors } & \multicolumn{2}{|c|}{ Overall } \\
\hline & & S.I & Rank & S.I & Rank & S.I & Rank \\
\hline & $\begin{array}{l}\text { Delay in payments by client for design } \\
\text { services }\end{array}$ & 4.32 & 1 & 4.18 & 1 & 4.24 & 1 \\
\hline & $\begin{array}{l}\text { staff allocation for many projects at the } \\
\text { same time }\end{array}$ & 4.21 & 2 & 4.06 & 3 & 4.12 & 2 \\
\hline & $\begin{array}{l}\text { Copying and modifying from previous work } \\
\text { to minimize time and cost }\end{array}$ & 4.07 & 4 & 4.09 & 2 & 4.08 & 3 \\
\hline & Tight design schedule & 4.11 & 3 & 3.97 & 4 & 4.03 & 4 \\
\hline & $\begin{array}{l}\text { lack of designer knowledge with techniques } \\
\text { and materials available in the market }\end{array}$ & 3.93 & 6 & 3.76 & 5 & 3.81 & 5 \\
\hline & $\begin{array}{l}\text { Inadequate time for checking of design } \\
\text { documents }\end{array}$ & 3.79 & 8 & 3.68 & 6 & 3.73 & 6 \\
\hline & $\begin{array}{l}\text { Selection of designers based on lowest } \\
\text { price }\end{array}$ & 4.01 & 5 & 3.46 & 8 & 3.69 & 7 \\
\hline & Lack of consultant experience & 3.80 & 7 & 3.38 & 9 & 3.55 & 8 \\
\hline & Lack of skilled design managers & 3.38 & 9 & 3.62 & 7 & 3.52 & 9 \\
\hline & $\begin{array}{l}\text { Change in project requirements by client at } \\
\text { later stages }\end{array}$ & 3.40 & 10 & 3.24 & 10 & 3.31 & 10 \\
\hline & Reduced design fees levels & 3.56 & 11 & 3.11 & 11 & 3.29 & 11 \\
\hline & $\begin{array}{l}\text { Inadequate design reviews with relevant } \\
\text { parties }\end{array}$ & 3.34 & 12 & 2.92 & 13 & 3.09 & 12 \\
\hline & $\begin{array}{l}\text { Inadequate design coordination between } \\
\text { design disciplines }\end{array}$ & 3.02 & 15 & 2.96 & 12 & 2.98 & 13 \\
\hline & Project complexity & 3.21 & 13 & 2.77 & 15 & 2.95 & 14 \\
\hline & Insufficient information from the client & 3.17 & 14 & 2.64 & 17 & 2.86 & 15 \\
\hline & Ineffective use of new technology & 2.83 & 16 & 2.87 & 14 & 2.85 & 16 \\
\hline & $\begin{array}{l}\text { Lack in number of staff in each } \\
\text { specialization (architect, structural... etc.) }\end{array}$ & 2.74 & 17 & 2.73 & 16 & 2.73 & 17 \\
\hline
\end{tabular}


Eigen value $\geq 1$ are identified, namely: delay in payments by client for design services, staff allocation for many projects at the same time, copying and modifying from previous work to minimize time and cost, and tight design schedule. The cumulative variance of the significant factors is $75.11 \%$. The $1^{\text {st }}$ ranked factor, delay in payments by client for design services, has Eigen value of 5.42 , while the $4^{\text {th }}$ ranked factor, tight design schedule, has Eigen value of 1.31 .

\section{Spearman rank correlation}

Equation (2) is used to check the correlation between contractors and consultants on the severity of design quality factors and delay factors. Result shows a good correlation between contractors and consultants on the severity of design quality factors $\left(r_{s}=0.79\right)$ and schedule delay factors $\left(r_{s}=0.83\right)$, so the study is reliable.

\section{Design quality and schedule delay in building construction projects}

Table 4 investigates the effect of significant design quality factors on schedule delay from the point of view of the targeted contractors and consultants. It shows the effect of these factors in relative ranks. According to $88 \%$ of respondents, "Delay in payments by client for design services" is the factor that has the highest effect on schedule delay. Delay of payment by the clients affects the ability of design office to complete its work smoothly. It also might affect the motivation of designers which negatively affect their morale and productivity. "Copying and modifying from previous work to minimize time and cost" ranked in the second position with relative index of value 0.61 . Due to low design fees, designers use designs from previous projects to save cost and time. On the contrary, copying and modifying from previous design works lead to mistakes in design that lead to change orders and rework during construction phase which delay the project. Closely "tight design schedule" and "staff allocation for many projects at the same time" ranked in the third and fourth positions with relative index of value 0.57 and 0.56 , respectively. Tight schedule gives designers less time for checking of design and contract documents. This leads to more and more mistakes in design which leads to time overrun. "staff allocation for many projects at the same time" leads for struggling with how to manage design-related tasks which affect design quality and designer productivity.

Result shows that the significant factors affecting design quality have high impact on schedule delay, so these factors should be controlled to improve project success in terms of time, cost and quality.

\begin{tabular}{|c|c|c|c|c|c|c|}
\hline \multirow{2}{*}{$\begin{array}{l}\text { Significant factors } \\
\text { affecting design quality } \\
\text { (Eigen values } \geq 1.0 \text { ) }\end{array}$} & \multicolumn{6}{|c|}{ Effect on schedule delay } \\
\hline & No effect & low effect & $\begin{array}{l}\text { moderate } \\
\text { effect }\end{array}$ & high effect & $\begin{array}{l}\text { extreme } \\
\text { effect }\end{array}$ & $\begin{array}{l}\text { Relative } \\
\text { index }\end{array}$ \\
\hline $\begin{array}{l}\text { Delay in payments by client } \\
\text { for design services }\end{array}$ & 0 & 1.85 & 9.8 & 60.15 & 28.2 & 0.64 \\
\hline $\begin{array}{l}\text { Copying and modifying from } \\
\text { previous work to minimize } \\
\text { time and cost }\end{array}$ & 0 & 3.1 & 13.6 & 60.2 & 23.1 & 0.61 \\
\hline Tight design schedule & 0 & 5.6 & 20.90 & 56.8 & 16.7 & 0.57 \\
\hline $\begin{array}{l}\text { staff allocation for many } \\
\text { projects at the same time }\end{array}$ & 0 & 8.4 & 22.6 & 51.1 & 17.9 & 0.56 \\
\hline
\end{tabular}

\section{Case study}

This study aims at establishing the effect of design quality on delay in residential building projects. To achieve this objective, data from 35 building projects executed in the West Bank in Palestine are gathered. Regression linear analysis is decided to be used to establish the relation between the con-
Table 4

Relationship between design quality and schedule delay in building projects 
sidered variables. This is because it is well-defined approach and widely used to describe the relation between dependent and independent variables (Mahamid, 2020).

In this case study, number of design changes is defined as an indicator for design quality and schedule delay is defined "as the time difference between the actual completion time and the planned completion time" (Mahamid et al., 2012). Data collected from available records in consultant offices and contracting firms in the West Bank in Palestine. All considered projects are residential buildings with 2-4 floors executed in the West Bank in the period between 2015 and 2020. To establish the regression model, number of design changes is considered as the independent variable $(\mathrm{x})$ and schedule delay in per cent is considered as the dependent variable (y). Results indicate that the average of schedule delay $=37 \%$ and the average number of design changes $=12$.

Fig. 2 and results obtained in Table 5 show a good linear relation between the dependent and independent variables $\left(R^{2}=0.71, F_{(1,34)}=76.19, p<0.05\right)$. Equation (3) presents the established model. The coefficient of design quality shows the magnitude of change in schedule delay due to changes in design which is 2.38 . So, if design changes increase in one unit, schedule delay will increase in 2.38 units. The intercept (constant) is 7.84 .

$$
y=2.83 x+7.84
$$

where: $y$-schedule delay in per cent, $x$ - number of design changes.

Fig. 2

Relation between design changes and schedule delay in building projects

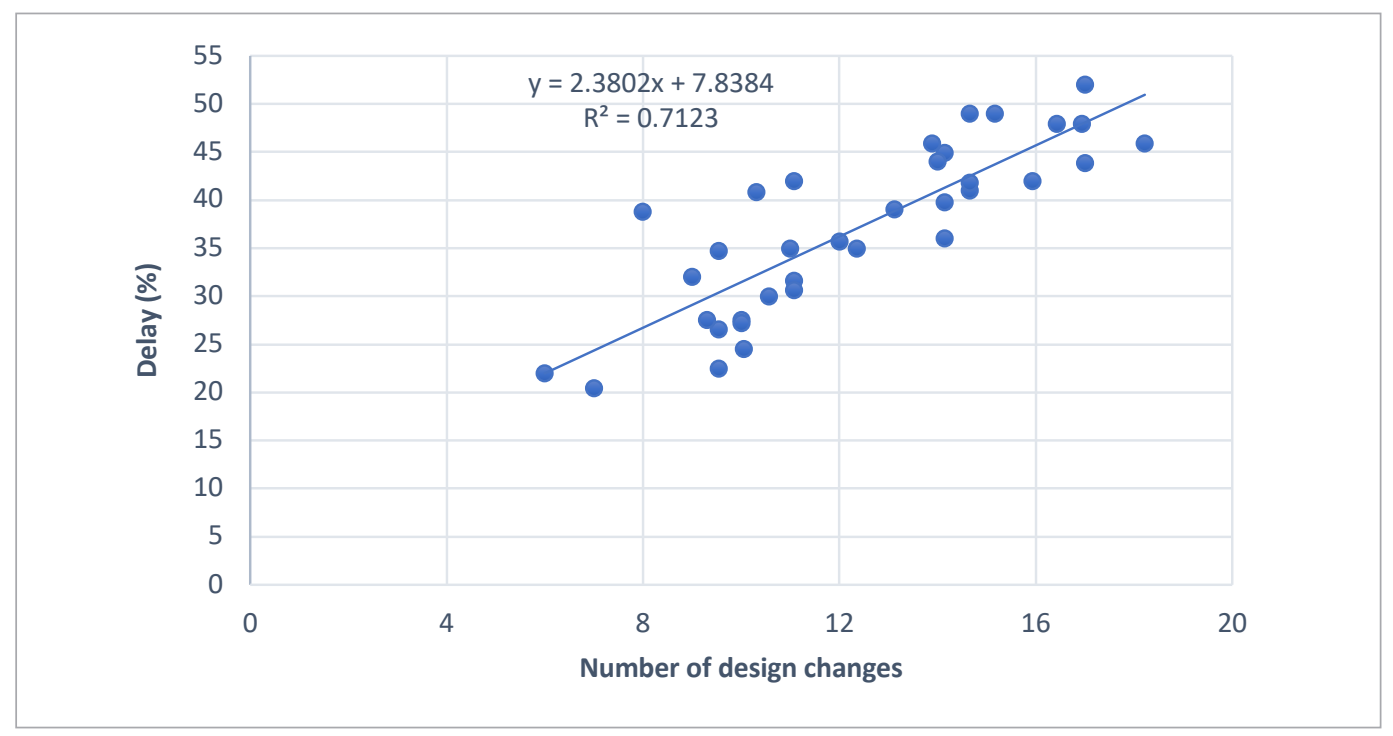

\section{Table 5}

Results of statistics for relation between design changes and schedule delay

\begin{tabular}{l|c|c|c}
\hline \multicolumn{3}{|c}{ Regression analysis results } \\
\hline Multiple R & 0.84 & & \\
\hline $\mathrm{R}^{2}$ & 0.71 & & \\
\hline Adjusted R & 0.7 & & \\
\hline $\mathrm{F}$ & 76.19 & & \\
\hline Observations & 35 & $t$ Stat & \\
\hline & Coefficients & 2.26 & \\
\hline Intercept & 7.84 & 8.72 & 0.030433 \\
\hline Design changes (\#) & 2.38 & & $7.41 \mathrm{E}-10$ \\
\hline
\end{tabular}


This study concludes that among the different factors that causes schedule delay, payments delay, poor labor productivity, lack of skilled manpower, frequent change orders and rework top the list. It also shows that among various factors affecting design quality, delay in payments by client for design services, staff allocation for many projects at the same time, copying and modifying from previous work to minimize time and cost, tight design schedule lack of designer knowledge with techniques and materials available in the market are the most significant factors. Spearman rank correlation test indicates a good agreement between contractors and consultants on the severity of schedule delay factors $\left(r_{s}=0.83\right)$ and factors of design quality $\left(r_{s}=0.79\right)$. Therefore, the study is reliable.

Factor analysis results indicate four major factors affecting design quality, namely: delay in payments by client for design services, staff allocation for many projects at the same time, copying and modifying from previous work to minimize time and cost, and tight design schedule. Respondents recognize that the significant factors of design quality have high impact on schedule delay, so these factors should be controlled and minimized by project management team in construction projects to enhance the overall performance.

The predictive model established using data from 35 building projects executed in the West Bank in Palestine implies a significant relationship between design quality and schedule delay. Equally, the relationship is directly proportional: more design changes occur, more delay will happen. More precisely, the model indicates that a unit increase (or decrease) in design changes results in 2.38 units increase (or decrease) in schedule delay.

Based on the output of this study, the following recommendations are suggested to improve design quality and to minimize schedule delay in building construction projects in Palestine.

a. Clients should fund the project effectively and should pay for design services on time. This is important to avoid unnecessary delays.

b. Contractors and sub-contractors should train labors to improve their skills which will improve their productivity and reduce project delay.

c. Enough time should be allowed for designers, so they can check and correlate all the information on all design documents. This will reduce mistakes in design and eventually project delay.

d. Enough staff should be appointed by deign offices. Designers should not be allocated for many projects because it will affect their ability to manage design-related tasks.

e. Suitable time frame should be given for planning designing, and bidding. All documents prepared in planning and design phases should be reviewed and checked to avoid any mistake. It will be very helpful in reducing change orders and rework during construction phase.

Abdelaziz, S. (2009). Factors Affecting the Quality of Design and Contractual Documents in Gaza Strip. Master thesis, The Islamic University of Gaza, Gaza.

Al-Hazim, N. and Abusalem, Z. (2015). Delay and cost overrun in road construction projects in Jordan. International Journal of Engineering \&Technology, Vol. 4 No. 2, pp. 288-293. https://doi.org/10.14419/ijet. v4i2.4409

Ali, A. S., Smith, A. \& Pitt, M. (2012). Contractors' perception of factors contributing to project delay: Case studies of commercial projects in Klang Valley, Malaysia. Journal of Design and Built Environment, 7(1), 43-57.

Conclusion

\section{References}

Assaf, S. and Al-Hejji, S. (2006). Causes of delay in large construction projects. International Journal of Project Management, 24(4), 349-357. https://doi. org/10.1016/j.ijproman.2005.11.010

Couto, J. (2012). Identifying of the reasons for the project design errors in the Portuguese construction industry. Natural and Applied Sciences, 3(2), 163-170.

Durdyev, S., Ismail, S. \& Bakar, N. A. (2010). Factors causing cost overruns in construction of residential projects: Case study of Turkey. Asian Journal of Management Research, 1(1), 3-12.

Emory, C. (1980), Business Research Methods, Revised Edition, Richard D. Irwin, Homewood, IL. 
Enshassi, A.; Lisk, R.; Sawalhi, I.; and Radwan, I. (2003). Contributors to construction delays in Palestine. The Journal of American institute of constructors, 27 (2), 45-53.

Faridi, A. and El-Sayegh, S. (2006). Significant factors causing delay in the UAE construction industry. Construction Management and Economics, 24(11), 11671176. https://doi.org/10.1080/01446190600827033

Gopang, M.; Imran, Q. ; and Nagapan, S. (2020). Assessment of Delay Factors in Saudi Arabia Railway/Metro Construction Projects . International Journal of Sustainable Construction Engineering and Technology, 11(2), 225-233. Retrieved from https://publisher.uthm.edu. my/ojs/index.php/IJSCET/article/view/7405. https:// doi.org/10.30880/ijscet.2020.11.02.028

Harnett, D. and Murphy, J. (1975), Introductory Statistical Analysis, Addison-Wesley Publishing.

Kaliba, C.; Muya, M.; and Mumba, K. (2009). Cost escalation and schedule delays in road construction projects in Zambia. International Journal of Project Management, 27(5), 522-531. https://doi.org/10.1016/j. ijproman.2008.07.003

Kpamma, E. and Adjei-Kumi, T. (2011). Management of waste in the building design process: The Ghanaian consultants' perspective. Architectural Engineering and Design Management, 7(2), 102-112. https:// doi.org/10.1080/17452007.2011.582333

Li, Y. \& Taylor, T. R. B. (2014). Modeling the impact of design rework on transportation infrastructure construction project performance. Journal of Construction Engineering and Management, 140(9), 1-8. https:// doi.org/10.1061/(ASCE)C0.1943-7862.0000878

Lopez, R. and Love, P. (2012). Design error costs in construction projects. Journal of Construction Engineering and Management, 138(5), 585-593. https://doi. org/10.1061/(ASCE)C0.1943-7862.0000454

Lopez, R. and Love, P. (2012). Design error costs in construction projects. Journal of Construction Engineering and Management, 138(5), 585-593. https://doi. org/10.1061/(ASCE)C0.1943-7862.0000454

Love, P.; Smith, J.; and Edwards, J. (2006). Contract Documentation and the Incidence of Rework in Projects. Architectural Engineering and Design Management, l 1, 247-259. https://doi.org/10.1080/1745200 7.2005 .9684596

Mahamid, I. (2017a). Schedule Delay in the KSA Road Construction Projects: Size, Estimate, Determinants, and Effects. International Journal of Architecture, Engineering and Construction Vol 6, No 3, 51-58. https://doi. org/10.7492/IJAEC.2017.017

Mahamid, I. (2017b). Analysis of Schedule Deviations in Road Construction Projects and the Effects of Project Physical Characteristics. Journal of Financial Management of Property and Construction, Vol 22, issue 2, pp.192-210. https://doi.org/10.1108/ JFMPC-07-2016-0031

Mahamid, I. (2020). Study of relationship between rework and labor productivity in building construction projects. Journal of Construction. 19 (1), 30 - 40. https://doi.org/10.7764/rdlc.19.1.30-41

Mahamid, I. and Bruland, A. (2011). Cost Overrun Causes in Road Construction Projects: Consultants' Perspective. 2nd International Conference on Construction and Project Management IPEDR vol.15 (Vol. 15, pp. 6-10). Singapore: IACSIT Press.

Mahamid, I.; Al-ghonamy , A.; and Aichouni, A. (2015). Risk Matrix for Delay Causes in Construction Projects in Saudi Arabia. Research Journal of Applied Sciences, Engineering and Technology 9(8): 665-670. https:// doi.org/10.19026/rjaset.9.1452

Mahamid, I.; Bruland, A.; and Dmaidi, N. (2012). Causes of delay in road construction projects. Journal of Management in Engineering, 28(3), 300-310. https://doi. org/10.1061/(ASCE)ME.1943-5479.0000096

Memon, A.; Rahman, l.; Akram, M.; and Ali, N. (2014). Significant factors causing time overrun in construction projects of Peninsular Malaysia. Modern Applied Science, 8(4), 16. https://doi.org/10.5539/mas.v8n4p16

Memon, A.; Rahman, I.; and Azis, A. (2012). Time and cost performance in construction projects in southern and central regions of peninsular $\mathrm{Ma}$ laysia. International Journal of Advances in Applied Sciences, Vol. 1 No. 1, pp. 45-52. https://doi. org/10.11591/ijaas.v1i1.537

Msafiri, A. (2015). An investigation into factors causing delays in road construction projects in Kenya. American Journal of Civil Engineering, 3 (3) , pp. 51-63. https://doi.org/10.11648/j.ajce.20150303.11

Omoregie, A. and Radford, D. (2006). Infrastructure delays and cost escalation: Causes and effects in Nigeria. Proceedings of the 6th International Postgraduate Research Conference in the Built and Human Environment, International Council for Research and Innovation in Building and Construction.

Pandit, D. (2015). Factors affecting construction project design development: a perspective from India. International Journal of Construction Supply Chain Management. 5 (2), 52-67. https://doi.org/10.14424/ ijcscm502015-52-67

Santoso, D. and Soeng, S. (2016). Analyzing delays of road construction projects in Cambodia: causes and effects. Journal of Management Engineering, Vol. 31 No. 6 , doi: 10.1061/(ASCE)ME.1943- 5479.0000467, 05016020 https://doi.org/10.1061/(ASCE)ME.1943-5479.0000467 
Sweis, G. (2013). Factors affecting time overruns in public construction projects: The case of Jordan. International Journal of Business and Management, 8(23), 120-129. https://doi.org/10.5539/ijbm. v8n23p120
Williams, C. and Johnson, P. (2013). Standards of professional practice for design management. Journal of Professional Issues in Engineering Education and Practice, 140(2), doi: 10.1061/(ASCE)El.19435541.0000190, 04013011. https://doi.org/10.1061/ (ASCE)El.1943-5541.0000190

\section{IBRAHIM MAHAMID}

\section{Professor}

Civil Engineering Department, Faculty of Engineering, University of Prince Mugrin.

\section{Main research area}

Cost and time estimating, project evaluation, risk and uncertainty management, construction contracts, productivity improvement, $\mathrm{BIM}$ and lean construction management

\section{Address}

University of Prince Mugrin, King Abdullah Road, Madinah, P.0 Box : 40202, Saudi Arabia

Tel.: 00966536659056

E-mail: imahamid@ymail.com

\section{About the Author}

